$\begin{array}{cl}\text { Türkiye Tarımsal Araştırmalar Dergisi } & \text { Turk J Agric Res } \\ \text { dergipark.gov.tr/tutad } & \text { 2017, 4(1): 50-58 } \\ \text { O TÜTAD } & \text { ISSN: 2148-2306 } \\ \text { e-ISSN: 2528-858X } & \text { doi: 10.19159/tutad.300661 }\end{array}$

\title{
Ağır Metal (Ni, Cd ve Cu) Uygulamalarının Andız Otu, Fener Otu ve Sığırkuyruğu Bitkilerinin Büyüme ve Gelişmesi Üzerine Etkisi"
}

\author{
Abdullah EREN ${ }^{* * *}$, Mehmet MERT ${ }^{2}$ \\ ${ }^{1}$ Mardin Artuklu Üniversitesi, Klzıltepe Meslek Yüksekokulu, Organik Tarım Bölümü, Mardin, TÜRKIYE \\ ${ }^{2}$ Mustafa Kemal Üniversitesi, Ziraat Fakültesi, Tarla Bitkileri Bölümü, Hatay, TÜRKIYYE
}

Geliş Tarihi/Received: 25.08 .2016

Kabul Tarihi/Accepted: 05.12.2016

**Sorumlu Yazar/Corresponding author: abdullaheren@artuklu.edu.tr

Özet: Bu çalışmada; nikel (Ni), kadmiyum $(\mathrm{Cd})$ ve bakır $(\mathrm{Cu})$ ile kirlenmiş topraklarda andız otu (Inula helenium), fener otu (Physalis angulata) ve sığırkuyruğu (Verbascum thapsus) bitkileri 6 hafta boyunca kontrollü koşullarda yetiștirilerek, bu metallerin topraklardan temizlenebilme olanakları araştırılmıştır. Denemede bitkilerin klorofil düzeyleri, biyokütle üretimi, ağır metal alımı ve indirgenmiş glutatyon (GSH) konsantrasyonları belirlenmiștir. Elde edilen bulgulara göre, bitkilerin dokularında biriktirdiği $\mathrm{Ni}, \mathrm{Cd}$ ve $\mathrm{Cu}$ konsantrasyonlarının toksisiteye neden olacak seviyelere ulaşmadığı tespit edilmiştir. En yüksek Ni içeriği $\left(253 \mu \mathrm{g} \mathrm{bitki}^{-1}\right)$ fener otu bitkisinin $400 \mathrm{mg} \mathrm{Ni} \mathrm{kg}^{-1}$ uygulamasından, en yüksek Cd içeriği ise fener otu (46.9 $\left.\mu \mathrm{g} \mathrm{bitki}^{-1}\right)$ ve sığırkuyruğu $\left(54.6 \mu \mathrm{g}\right.$ bitki-1 $\left.^{-1}\right)$ bitkilerinde $10 \mathrm{mg} \mathrm{Cd} \mathrm{kg}^{-1}$ uygulamasından ve en yüksek $\mathrm{Cu}$ konsantrasyonu ise fener otu (304 $\left.\mu \mathrm{g} \mathrm{bitki}^{-1}\right)$ bitkisinin $200 \mathrm{mg} \mathrm{Cu} \mathrm{kg}^{-1}$ uygulamasından elde edilmiştir. Deneme sonucunda fener otu ve sığırkuyruğu bitkilerinin ağır metallerle kirlenmiş toprakların temizlenmesinde kullanma potansiyellerinin olduğu tespit edilmiştir.

Anahtar Kelimeler: Yabani ot, nikel, kadmiyum, bakır, fitoremediasyon, toprak kirliliği

\section{The Effect of Heavy Metal Applications ( $\mathrm{Ni}, \mathrm{Cd}$ and $\mathrm{Cu}$ ) on Growth and Development of Elecampane, Groundcherry and Mullein}

\begin{abstract}
This study was conducted to investigate the phytoremediation potential of Inula helenium, Physalis angulata and Verbascum thapsus species which are grown on nickel $(\mathrm{Ni})$, cadmium $(\mathrm{Cd})$ and copper $(\mathrm{Cu})$ polluted soils under controlled conditions for 6 weeks. The chlorophyll levels, biomass production, heavy metal uptake and concentrations and reduced glutathione concentrations were determined. According to the level of $\mathrm{Ni}, \mathrm{Cd}$, and $\mathrm{Cu}$ in the test plants did not reach to toxic levels. Results showed that Physalis angulata had the highest Ni content $253 \mu \mathrm{g}$ plant ${ }^{-1}$ with the $400 \mathrm{mg} \mathrm{Ni} \mathrm{kg}^{-1} \mathrm{application}$ the highest $\mathrm{Cd}$ was obtained from Physalis angulata $\left(46.9 \mu \mathrm{g} \mathrm{plant}^{-1}\right)$ and Verbascum thapsus $\left(54.6 \mu \mathrm{g} \mathrm{plant}^{-1}\right)$ with $10 \mathrm{mg}$ $\mathrm{Cd} \mathrm{kg}^{-1}$ application and Physalis angulata had the highest $304 \mu \mathrm{g} \mathrm{Cu}$ with the $200 \mathrm{mg} \mathrm{Cu} \mathrm{kg}{ }^{-1}$ application. It can be concluded that Physalis angulata and Verbascum thapsus have potential to clean-up $\mathrm{Ni}, \mathrm{Cu}$ and $\mathrm{Cd}$ polluted soils.
\end{abstract}

Keywords: Weed, nickel, cadmium, copper, phytoremadiation, soil pollution

\section{Giriș}

Toprak kirliliği, toprağın fiziksel, kimyasal, biyolojik ve jeolojik yapısının bozulmasıdır. Yanlış tarım tekniklerinin uygulanması, yanlış ve gereğinden fazla gübre ile tarımsal ilaçların kullanılması, endüstriyel ve evsel atıklarda bulunan zehirli ve tehlikeli maddelerin topraklarda birikmesi gibi antropojenik faaliyetler sonucunda topraklar kirlenmektedir (Dağhan, 2007; Karaca ve Turgay, 2012; Dağhan ve Öztürk, 2015).

Topraktaki kirleticilerden bazıları zamanla kendiliğinden, bazıları da fiziksel veya kimyasal

\footnotetext{
*: Bu çalışma, Mustafa Kemal Üniversitesi Fen Bilimleri Enstitüsü Doktora Tez çalışmasından üretilmiştir.
} 
yollarla kolayca temizlenebilirken; ağır metaller ise topraklarda kalıcılığı yüksek ve temizlenmesi zor olan kirleticilerdir. Bu bağlamda Scheffer ve Schachtschabel (1989), yaptıkları bir araştırmada topraklara kimyasal olarak ilave edilen elementlerden en önemli olumsuz etkiyi ağır metallerin yaptığını ve doğal kaynaklar üzerindeki ağır metal yoğunluğunun gittikçe artan düzeyde devam ettiğini bildirmişlerdir.

Ağır metallerin bazıları (Çinko, Zn; demir, Fe; bakır, $\mathrm{Cu}$; mangan, $\mathrm{Mn}$; vb) canlılar için gerekli olmalarına rağmen yüksek dozlarda hepsi canlılarda toksik etkiye neden olmaktadırlar (Dağhan, 2011). Toprağı kirleten ağır metallerin en tehlikeli yanı bitki tarafından alınmaları ile besin zincirine katılarak diğer canlılara olumsuz etkide bulunmalarıdır. Ayrıca ağır metallerin toprak içerisindeki konsantrasyonları arttıça taban suyuna sızarak, buradan elde edilecek tarımsal ve içme sularının niteliğini bozmaktadırlar. Bunların dışında, ağır metaller toprak canlılarının aktivitelerini etkileyerek, işlevlerine engel olur, dolayısıyla ekolojik dengeyi olumsuz yönde etkilerler (Çepel, 2003; Dağhan, 2011).

Günümüzde, özellikle tarım alanlarında verimi artırmak için kullanılan diamonyum fosfat (DAP), triple süper fosfat (TSP) ve kompoze gübrelerinde Cd içeriği yüksektir (>8 $\mathrm{mg} \mathrm{kg}^{-1}$ gübre); ayrıca, Türkiye'de üretilen gübrelerde yaklaşık $\%$ 87'sinde $8 \mathrm{mg} \mathrm{Cd} \mathrm{kg}^{-1}$ gübre sınır değerine yakın (7.5 mg Cd $\mathrm{kg}^{-1}$ gübre) ya da 2-5 kat üzerindedir. $\mathrm{Bu}$ durum ülkemizde gübre tüketiminin yoğun olduğu tarım alanlarının kirlendiğinin ya da gelecekte kirlenme olasılığına sahip olduğunun bir göstergesidir (Köleli ve Kantar, 2006). Diğer yandan; antropojenik, maden, fosil yakıtlar, tarımsal ve endüstriyel faaliyetler sonucu toprakların her geçen gün $\mathrm{Ni}$ ve diğer ağır metallerce de kirlenmektedir (Yusuf ve ark., 2011). Bakır (Cu), doğal yollarla volkanik patlamalar ve çevredeki tozların havaya karışmasıyla ve insan faaliyetleriyle (maden atıkları, boya, ahşap koruyucular, tesisatlar ve pestisitler) doğaya karıșmakta ve ekosisteme girmektedir (Güler ve Çobanoğlu, 1997; Kabata Pendias ve Mukherjee, 2007).

Ağır metallerin neden olduğu çevre kirliliği tüm dünyanın dikkatini çektiği ve araştırdığı bir konudur. Son yıllarda yapılan çalışmalar; ağır metallerin kaynakları ve davranışları, çevre ve insan sağlığı üzerindeki etkileri, kirlenen alanların tespiti ve tespit edilen bu alanların ekosistem ve insan sağlı̆̆ına zarar vermesinin önüne geçmek için temizleme yöntem ve olanakları üzerine yoğunlaşmıştır. $\mathrm{Bu}$ bağlamda ağır metalle kirlenmiş topraklar fiziksel, kimyasal ve biyolojik yöntemlerle temizlenebilmektedir (Kocaer ve Başkaya, 2003).

Biyolojik temizleme yöntemi içerisinde yer alan fitoremediasyon yöntemi toprak ve sudaki organik ve inorganik kirleticilerin bitki kökleri tarafından alınıp, yeşil aksama taşınmasını veya inaktif hale getirilmesini ifade etmektedir. Fitoremediasyon ucuz, doğa dostu, geniş alanlara uygulanabilen ve estetik özellikleri nedeniyle son yıllarda tercih edilen bir yöntemdir (Dağhan ve Öztürk, 2015). Glass (1999) yaptı̆̆ı bir ekonomik analizde; ağır metallerle kirlenmiş bir alanın toprakla doldurulması için 100-500 \$ ton ${ }^{-1}$, kimyasal kullanılarak temizlemesi için 100-500 \$ ton $^{-1}$ ve fitoekstraksiyonla temizlemek içinse 5-40 $\$$ ton $^{-1}$ harcandığ 1 tespit etmiştir.

Fitoremediasyon yönteminde yetiştirilecek bitkinin; bol yeşil aksamlı ve hasat edilebilir bu aksamında yüksek oranda metal biriktirmesi, biriken ağır metali tolere etmesi, hızlı büyüyebilen derin köklü ve kolayca hasat edilebilir olması gerekmektedir (Dağhan ve ark., 2012). Bu nedenle birçok araştırıcı farklı bitkilerin değișen kirlilik seviyelerinde ağır metallerin temizlenmesinde kullanılabilirliğini araştırmıştır. $\mathrm{Bu}$ çalışmanın amac1; özellikle doğada çok rahat yetişebilen ve bol yeşil aksam üreten ve yabani ot olarak bilinen andiz otu (Inula helenium), fener otu (Physalis angulata) ve sığırkuyruğu (Verbascum thapsus) bitkilerinin $\mathrm{Ni}, \mathrm{Cd}$ ve $\mathrm{Cu}$ ile kirlenmiș topraklarda yetiştirilerek; ağır metalleri alım, biriktirme ve fitoekstraksiyon yönteminde kullanılabilme potansiyellerinin araştırılmasıdır.

\section{Materyal ve Yöntem}

Araştırmada bitki materyali olarak; çok yıllık andız otu (Inula helenium), tek y1llik fener otu (Physalis angulata) ve iki yıllık sığırkuyruğu (Verbascum thapsus) bitkileri kullanılmıştır.

Araştırmaya konu ağır metaller kadmiyum (Cd), nikel (Ni) ve bakır (Cu)'dır. Denemeler 3x5 faktöriyel deneme deseninde 3 tekerrürlü olarak saksılarda yürütülmüştür. Deneme konuları; her bir ağır metal için, 3 bitki türü ve 5 ağır metal dozundan oluşmuştur. Toplam 135 (3 bitki x 3 tekerrür x 3 ağır metal x 5 doz olarak) saksı denemeye alınmıştır.

Denemede toprak materyali olarak Mollisol toprak ordosunda yer alan (Kılıç ve ark., 2008) ve Amik Ovası'nın yaygın toprak serilerinden biri olan Paşaköy serisi toprağı kullanılmıştır. Deneme toprağının bazı fiziksel ve kimyasal özellikleri Tablo 1'de verilmiştir.

Saks1 denemeleri; 2012 yılında, Mustafa Kemal Üniversitesi, Toprak Bilimi ve Bitki Besleme 
Tablo 1. Araştırmada kullanılan Paşaköy serisi deneme toprağının bazı fiziksel ve kimyasal özellikleri

\begin{tabular}{|c|c|c|}
\hline Toprak özellikleri & Değerler & Kaynaklar \\
\hline Tekstür Sınıfı & C (Killi) & Bouyoucus, 1952 \\
\hline $\mathrm{pH}$ & 7.56 & Anonymous, 1951 \\
\hline Tuz $(\%)$ & 0.216 & Anonymous, 1951 \\
\hline $\mathrm{CaCO}_{3}(\%)$ & 45.06 & Loeppert ve Suarez, 1996 \\
\hline Organik madde $(\%)$ & 2.55 & Kacar, 1995 \\
\hline Tarla kapasitesi (\%) & 32.4 & Alpaslan ve ark., 1998 \\
\hline Toplam N (\%) & 1.12 & Bremner, 1965 \\
\hline Alınabilir $\mathrm{P}\left(\mathrm{mg} \mathrm{P}_{2} \mathrm{O}_{5} \mathrm{~kg}^{-1}\right)$ & 19.14 & Olsen ve ark., 1954 \\
\hline Alınabilir $\mathrm{K}\left(\mathrm{mg} \mathrm{K}_{2} \mathrm{O} \mathrm{kg}^{-1}\right)$ & 77.28 & Richards, 1954 \\
\hline Alınabilir $\mathrm{Cu}\left(\mathrm{mg} \mathrm{kg}^{-1}\right)$ & 3.73 & Lindsay ve Norvell, 1978 \\
\hline Alınabilir Ni $\left(\mathrm{mg} \mathrm{kg}^{-1}\right)$ & 7.34 & Lindsay ve Norvell, 1978 \\
\hline Alınabilir Cd $\left(\mathrm{mg} \mathrm{kg}^{-1}\right)$ & 0.04 & Lindsay ve Norvell, 1978 \\
\hline
\end{tabular}

Bölümü, iklimlendirme odasında kurulmuştur. Saksılara 4 mm'lik elekten elenmiş toprak örneklerinden 2.5 L'lik saksılara $2 \mathrm{~kg}$ hava kuru toprak doldurulmuştur. Denemede uygulanacak $\mathrm{Cd}$, Ni ve $\mathrm{Cu}$ dozları Lindsay (1979) tarafindan bildirilen ortalamalar ve üst limitler göz önünde bulundurularak belirlenmiştir. Toprakta homojen bir dağılım sağlamak için saksılara ekim öncesinde artan dozlarda Cd (0-5-10-20-40 mg kg-1, $3 \mathrm{CdSO}_{4} .8 \mathrm{H}_{2} \mathrm{O}$ formunda), $\mathrm{Ni}$ (0-50-100-200-400 $\mathrm{mg} \mathrm{kg}{ }^{-1}, \mathrm{NiSO}_{4} \cdot 6 \mathrm{H}_{2} \mathrm{O}$ formunda) ve $\mathrm{Cu}(0-100-$ 200-400-800 mg kg-1, $\mathrm{CuSO}_{4} .5 \mathrm{H}_{2} \mathrm{O}$ formunda) çözelti şeklinde uygulanmış ve saksı toprağı tarla kapasitesinin \% 60-80'ine getirilerek 3 hafta süreyle kontrollü koşullarında inkübasyona bırakılmıștır. Ekimden önce, her saksıya $\mathrm{NH}_{4} \mathrm{SO}_{4}$ formunda $200 \mathrm{mg} \mathrm{kg}^{-1}$ azot $(\mathrm{N}), \mathrm{KH}_{2} \mathrm{PO}_{4}$ formunda $100 \mathrm{mg} \mathrm{kg}^{-1}$ fosfor (P) ve $125 \mathrm{mg} \mathrm{kg}^{-1}$ potasyum (K) ile Fe-EDTA formunda $2.5 \mathrm{mg} \mathrm{kg}^{-1}$ demir (Fe) çözelti şeklinde uygulanmıştır. Deneme süresince saksılar tarla kapasitesi \% 60-80 olacak şekilde deiyonize su ile sulanmıştır. Kadmiyum, Ni ve $\mathrm{Cu}$ uygulanmış saksılarda, 6 hafta süre ile bitkiler çiçeklenmeye kadar yetiştirilmiştir.

Deneme sonunda bitkiler toprak yüzeyinin yaklaşık $1 \mathrm{~cm}$ üzerinden hasat edilip saf suyla yıkanmış, ardından kurutma dolabında $65{ }^{\circ} \mathrm{C}$ 'de sabit ağırlığa gelinceye kadar kurutulmuştur. Daha sonra bitkilerin kuru ağırlıkları alınarak bitki analizleri için agat taşlı bitki öğütme değirmeninde (Retsch RM 200) ögütülmüştür. Deneme sonuçları tüm bitki olarak değerlendirilmiştir. Öğütülen bitki örnekleri nitrik asit $\left(\mathrm{HNO}_{3}\right)$ ile mikro dalga firında (MarsXpress CEM) çözünürleştirilerek $\mathrm{Ni}, \mathrm{Cd}$ ve $\mathrm{Cu}$ konsantrasyonları ICP-AES cihazında ölçülmüştür.

Bitkilere $\mathrm{Cd}, \mathrm{Ni}$ ve $\mathrm{Cu}$ uygulamasının etkisiyle yapraklarda değişen klorofil içerikleri, bitkiler hasat edilmeden önce klorofil ölçüm cihazı (Konica-Minolta SPAD-502) ile 3 yinelemeli olarak ölçülmüştür.
İndirgenmis glutatyon analizi (GSH), Cakmak ve Marschner (1992)'ye göre yapılmıștır. Yaklaşık olarak $0.5 \mathrm{~g}$ yaş yaprak örneği $5 \mathrm{~mL} \% 5$ metafosforik asitle ekstrakte edilerek, $400 \mathrm{rpm}$ 'de 30 dakika santrifüj edilmiştir. Santrifüj tüpünün üstünde kalan çözeltiden (supernatant) $0.5 \mathrm{~mL}$ çözelti alınarak üzerine fosfat tamponu ( $\mathrm{pH} 7.4)$ içinde hazırlanmış $0.5 \mathrm{~mL}$ DTNB (5.5'-dithiobis 2nitrobenzoik asit) ilave edilmiștir. Standart olarak 0-100 $\mu \mathrm{g} \mathrm{L}^{-1}$ aralığında redükte glutatyon \% 5'lik meta-fosforik asit (w/v) içinde hazırlanmıştır. Örnekler ve glutatyon ile hazırlanan standartlar 20 dakika sonra $412 \mathrm{~nm}$ 'de spektrofotometre ile konsantrasyonları belirlenmiştir.

Saksı denemeleri sonucunda elde edilen veriler SPSS 17.0 istatiksel analiz programı kullanılarak $3 \times 5$ faktöriyel deneme desenine göre değerlendirilmiş ve Bek (1986)'e göre Duncan testi uygulanarak gruplandırılmıştır.

\section{Bulgular ve Tartışma}

\subsection{Nikel denemesi}

Artan dozlarda Ni uygulamalarının andiz otu, fener otu ve sığırkuyruğu bitkilerinin; yaş ağırlık, kuru ağırlık, klorofil, GSH ve bitkideki konsantrasyonlarına etkileri Tablo 2'de verilmiştir.

Nikel dozlarındaki artışla bitkilerin kuru ağırlıklarında azalmalar gözlenmiştir. Artan Ni uygulamalarında bitkiler arasında en düşük bitki kuru ağırlığ $1.85 \mathrm{~g} \mathrm{bitki}^{-1}$ ile andız otu, en yüksek bitki kuru ağırlığ 1 ise $6.38 \mathrm{~g} \mathrm{bitki}^{-1}$ ile fener otunda elde edilmiştir. Uygulama dozları arasındaki en düşük bitki kuru ağırlığı (3.93 g bitki $\left.^{-1}\right) 400$ mg Ni $\mathrm{kg}^{-1}$ uygulamasında, en yüksek bitki kuru ağırlığ (5.11 $\left.\mathrm{g} \mathrm{bitki}^{-1}\right)$ ise kontrol uygulamasında tespit edilmiştir (Tablo 2). Benzer sonuçlar diğer araştırmacılar tarafindan yapılan çalışmalarda da elde edilmiştir. Pandey ve Sharma (2002), lahana bitkisinin metabolizmasında ve gelişiminde ağır metallerden $\mathrm{Ni}$ ve $\mathrm{Cd}$ etkilerini inceledikleri bir çalışmada, kontrol bitkisine göre; $500 \mu \mathrm{M}$ 
uygulamalarında gövde ve yaprak kuru ağırlığının azaldığını ve metabolizma ile ilgili özelliklerin de olumsuz yönde etkilendiğini tespit etmişlerdir. Alam ve ark. (2007), Ni uygulamalarının Brassica juncea bitkisinin kuru ağırlığında azalmalara neden olduğunu tespit etmiştir.

Nikel dozlarındaki artışla birlikte; andız otu, fener otu ve sığırkuyruğu bitkilerinin klorofil miktarları 22.0-42.9 arasında bir değişim göstermiştir. Bitkiler arasında klorofil miktarları en düşük 26.2 ile fener otunda, en yüksek değer (39.4) ise sığırkuyruğunda; dozlar arasındaki en düşük SPAD değeri (28.6) $400 \quad \mathrm{mg} \quad \mathrm{Ni} \quad \mathrm{kg}^{-1}$ uygulamasında, en yüksek SPAD değeri (33.2) ise kontrol uygulamasında tespit edilmiştir (Tablo 2). Ewais (1997), Cyperus difformis, Chenopodium ambrosioides ve Digitaria Sanguinolis bitki türleri ile yaptığı bir çalışmasında; artan dozlarda $\mathrm{Ni}$ $\left(0,50,100\right.$ ve $\left.200 \mathrm{mg} \mathrm{kg}^{-1}\right)$ ve $\mathrm{Cd}(0,5,10$ ve 20 $\mathrm{mg} \mathrm{kg}^{-1}$ ) uygulamalarının bitki gelişimi ile bitkilerde klorofil ve protein içeriklerine etkisini incelemiş; araştırma sonucu ağır metal dozları arttıkça tüm türlerin gelişmelerinde önemli düzeylerde azalmalar meydana geldiğini, ayrıca ağır metallerin klorofil ve pigment içeriğini de olumsuz etkilediğini göstermiștir. Benzer şekilde Zengin ve Munzuroğlu (2005), fasulyede artan Ni dozlarının (0.1, 0.3 ve $0.5 \mathrm{mM}$ ) klorofil a, klorofil b, karotenoidler, total pigment I ve total pigment II miktarını azalttığını belirlemişlerdir.

Bitkilerin GSH konsantrasyonları kontrole göre Ni dozlarındaki artışla birlikte artmıştır. Farklı Ni uygulamalarında, bitkiler arasında en düşük GSH konsantrasyonu 300 ve $301 \mu \mathrm{g} \mathrm{mL}^{-1}$ sığırkuyruğu ve andız otu bitkilerinde, en yüksek $410 \mu \mathrm{g} \mathrm{mL}^{-1}$ ise fener otu bitkisinde tespit edilmiştir (Tablo 2). Dağhan ve ark. (2012) tarafindan yapılan bir çalışmada benzer sonuçlar elde edilmiştir. Araştırmacılar artan dozlarda $\mathrm{Ni}$ uyguladıkları topraklarda transgenik ve transgenik olmayan tütün bitkilerinin indirgenmiş glutatyon konsantrasyonlarında artış olduğunu tespit etmiştirler. Göreceli olarak yüksek stabilite ve suda yüksek çözünürlük glutatyonu bitkilerin oksidatif, ağır metal ve bazı iç ve dış organik yapıların streslerinden korunmasında biyokimyasal olarak ideal yapmaktadır (Millar ve ark., 2003; Foyer ve Noctor, 2005; Rausch ve ark., 2007).

Tablo 2. Nikelin farklı doz uygulamalarının, andız otu, fener otu ve sığırkuyruğu bitkilerinin yaş ağırlık, kuru ağırlık, klorofil, GSH ve bitkideki Ni konsantrasyonları üzerine etkileri

\begin{tabular}{|c|c|c|c|c|c|c|}
\hline Çeşitler & $\begin{array}{c}\mathrm{Doz} \\
\left(\mathrm{mg} \mathrm{kg}^{-1}\right)\end{array}$ & $\begin{array}{l}\text { Kuru ağırlık } \\
\left(\mathrm{g} \text { bitki }{ }^{-1}\right)\end{array}$ & $\begin{array}{l}\text { Klorofil } \\
\text { (SPAD) }\end{array}$ & $\begin{array}{c}\mathrm{GSH} \\
\left(\mu \mathrm{g} \mathrm{mL}^{-1}\right)\end{array}$ & $\begin{array}{l}\text { Ni Konsantrasyonu } \\
\left(\mathrm{mg} \mathrm{kg}^{-1}\right)\end{array}$ & $\begin{array}{c}\mathrm{Ni} \\
\text { içeriği } \\
\left(\mu \mathrm{g} \mathrm{bitki}{ }^{-1}\right)\end{array}$ \\
\hline & 0 & 3.361 & $31.4 \mathrm{~d}$ & $263 \mathrm{j}$ & 1.141 & $3.83 \mathrm{~h}$ \\
\hline & 50 & $1.55 \mathrm{j}$ & $29.0 \mathrm{f}$ & 2901 & $29.4 \mathrm{e}$ & $45.5 \mathrm{~g}$ \\
\hline \multirow[t]{5}{*}{ Andiz otu } & 100 & $1.12 \mathrm{k}$ & $22.0 \mathrm{j}$ & $305 \mathrm{~h}$ & $29.8 \mathrm{e}$ & $33.4 \mathrm{~g}$ \\
\hline & 200 & $1.59 \mathrm{j}$ & $30.1 \mathrm{e}$ & $348 \mathrm{~g}$ & $41.5 \mathrm{c}$ & $65.8 \mathrm{f}$ \\
\hline & 400 & $1.63 \mathrm{j}$ & $30.0 \mathrm{e}$ & $300 \mathrm{~h}$ & $51.2 \mathrm{a}$ & $83.4 \mathrm{e}$ \\
\hline & 0 & $6.09 \mathrm{dc}$ & $26.5 \mathrm{~g}$ & $378 \mathrm{e}$ & 2.491 & $15.1 \mathrm{~h}$ \\
\hline & 50 & $7.24 \mathrm{a}$ & $29.2 \mathrm{f}$ & $470 \mathrm{a}$ & $12.3 \mathrm{~h}$ & $88.8 \mathrm{e}$ \\
\hline \multirow[t]{5}{*}{ Fener otu } & 100 & $6.70 \mathrm{~b}$ & $25.6 \mathrm{~h}$ & $382 \mathrm{e}$ & $12.3 \mathrm{~h}$ & $81.9 \mathrm{e}$ \\
\hline & 200 & $6.33 \mathrm{c}$ & $25.5 \mathrm{~h}$ & $398 \mathrm{~d}$ & $22.4 \mathrm{f}$ & $141 \mathrm{c}$ \\
\hline & 400 & $5.54 \mathrm{f}$ & 24.31 & $420 \mathrm{c}$ & $45.6 \mathrm{~b}$ & $253 \mathrm{a}$ \\
\hline & 0 & $5.88 \mathrm{ed}$ & $41.7 \mathrm{~b}$ & $269 j$ & 2.071 & $12.2 \mathrm{~h}$ \\
\hline & 50 & $5.74 \mathrm{fe}$ & $39.1 \mathrm{c}$ & $175 \mathrm{~m}$ & $13.7 \mathrm{~h}$ & $78.5 \mathrm{fe}$ \\
\hline \multirow[t]{3}{*}{ Sığırkuyruğu } & 100 & $5.75 \mathrm{fe}$ & $41.8 \mathrm{~b}$ & $440 \mathrm{~b}$ & $18.0 \mathrm{~g}$ & $103 \mathrm{~d}$ \\
\hline & 200 & $4.97 \mathrm{~g}$ & $42.9 \mathrm{a}$ & $251 \mathrm{k}$ & $27.5 \mathrm{e}$ & $136 \mathrm{c}$ \\
\hline & 400 & $4.63 \mathrm{~h}$ & $31.5 \mathrm{~d}$ & $367 \mathrm{f}$ & $36.7 \mathrm{~d}$ & $170 \mathrm{~b}$ \\
\hline \multicolumn{7}{|l|}{$\operatorname{Doz}\left(\mathrm{mg} \mathrm{kg}^{-1}\right)$} \\
\hline 0 & & $5.11 \mathrm{~A}$ & $33.2 \mathrm{~A}$ & $303 \mathrm{E}^{*}$ & $1.90 \mathrm{E}^{*}$ & $10.4 \mathrm{D}^{*}$ \\
\hline 50 & & $4.84 \mathrm{~B}$ & $32.4 \mathrm{~B}$ & $312 \mathrm{D}$ & $18.5 \mathrm{D}$ & $70.9 \mathrm{C}$ \\
\hline 100 & & $4.52 \mathrm{C}$ & $29.8 \mathrm{C}$ & $376 \mathrm{~A}$ & $20.0 \mathrm{C}$ & $72.9 \mathrm{C}$ \\
\hline 200 & & $4.30 \mathrm{D}$ & $32.8 \mathrm{BA}$ & $332 \mathrm{C}$ & $30.5 \mathrm{~B}$ & $115 \mathrm{~B}$ \\
\hline 400 & & $3.93 \mathrm{E}^{*}$ & $28.6 \mathrm{D}^{*}$ & $362 \mathrm{~B}$ & $44.5 \mathrm{~A}$ & $169 \mathrm{~A}$ \\
\hline \multicolumn{7}{|l|}{ Çeşit } \\
\hline And1z otu & & $1.85 \mathrm{C}^{*}$ & $28.5 \mathrm{~B}$ & $301 \mathrm{~B}^{*}$ & $30.6 \mathrm{~A}$ & $46.4 \mathrm{C}^{*}$ \\
\hline Fener otu & & $6.38 \mathrm{~A}$ & $26.2 \mathrm{C}^{*}$ & $410 \mathrm{~A}$ & $19.0 \mathrm{~B}^{*}$ & $116 \mathrm{~A}$ \\
\hline Sığırkuyruğu & & $5.39 \mathrm{~B}$ & $39.4 \mathrm{~A}$ & $300 \mathrm{~B}^{*}$ & $19.6 \mathrm{~B}^{*}$ & $100 \mathrm{~B}$ \\
\hline
\end{tabular}

*: Aynı satır ve sütun içinde aynı harfle gösterilen ortalamalar arasındaki fark Duncan-testine göre $\mathrm{P} \leq 0.01$ hata sınırları içinde önemsizdir. Büyük harfler ağır metal dozu ve bitki ortalamalarına ait esas etkilerin, küçük harfler ise bitki x doz interaksiyonlarına ait ortalamaların karșılaştırılmasıdır. 
Bitkilerin yeşil aksam Ni konsantrasyonları Ni dozlarındaki artışla artış göstermiştir. En yüksek $\mathrm{Ni}$ konsantrasyonu (44.5 mg kg-1) $400 \mathrm{mg} \mathrm{Ni} \mathrm{kg}{ }^{-1}$ uygulamasında elde edilmiştir (Tablo 2). Bitkiler arasında ise en yüksek $\mathrm{Ni}$ konsantrasyonu (30.6 mg Ni kg-1) andız otunda tespit edilmiştir. Ancak bitkilerin kuru ağırlıkları dikkate alınarak hesaplanan (metal konsantrasyonu x kuru ağırlık) $\mathrm{Ni}$ içeriği en düşük (46.4 $\mu \mathrm{g} \mathrm{Ni}$ bitki $\left.^{-1}\right)$ andız otu bitkisinde, en yüksek ise $\left(116 \mu \mathrm{g} \mathrm{Ni}\right.$ bitki $\left.^{-1}\right)$ fener otu bitkisinde saptanmıştır. Sonuçlar fitoremediasyon yönteminde kullanılacak bitkinin yeşil aksamında biriktirebildiği ağır metal konsantrasyonu kadar bitkinin ürettiği yeşil aksam miktarının da çok önemli olduğunu göstermektedir. Diğer yandan bitkilerde ağır metal konsantrasyonlarının sınır değerlerinin Alloway (1995)'in bildirdiği kritik konsantrasyon (10-100 $\mathrm{mg} \mathrm{Ni} \mathrm{kg}{ }^{-1}$ ) aralığında olduğu da tespit edilmiştir.

\subsection{Kadmiyum denemesi}

Artan dozlarda Cd uygulamasının bitkilerin kuru ağırlıklarında azalmalara neden olduğu Tablo 3 'te görülmektedir. Kadmiyum dozundaki artış sonucunda fener otu bitkisi toksik etkiye rağmen en fazla kuru ağırlık (6.86 $\left.\mathrm{g} \mathrm{bitki}^{-1}\right)$ üreten bitki olmuştur. Fener otu bitkisini sırasıyla sığırkuyruğu (3.58 $\left.\mathrm{g} \mathrm{bitki}^{-1}\right)$ ve andız otu (2.02 $\left.\mathrm{g} \mathrm{bitki}^{-1}\right)$ takip etmiştir. Benzer sonuçlar Bayçu ve Önal (1993) tarafından yapılan bir araştırmada da gözlenmiştir. Araştırmacılar, $50 \mathrm{mg} \mathrm{kg}{ }^{-1} \mathrm{Cd}$ konsantrasyonu içeren kum kültüründe, yedi hafta süre ile yetiştirdikleri Ailanthus altissima fidelerinde; hafif kloroz ve yaprakların kuru ağırlıklarında \% 40 azalma gözlemlemişlerdir. Kalınbacak ve ark. (2012), yapmış oldukları bir araştırmada; 0, 5, 15,

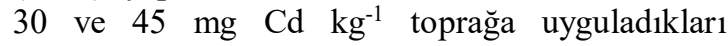
saksılarda yetiştirdikleri buğday bitkisinin $\mathrm{Cd}$ toksisitesinden olumsuz etkilendiğini ve $\mathrm{Cd}$ miktarı arttıkça buğdayın kuru ağırlığında azalma olduğunu saptamışlardır. Araştırmacılar en yüksek buğday kuru ağırlığını; kontrol bitkisinde, en düşük ise $45 \mathrm{mg} \mathrm{Cd} \mathrm{kg}^{-1}$ uygulamasından elde etmişlerdir. Ayrıca artan düzeylerde uygulama ile bitki verimi azalırken, bitkilerde $\mathrm{Cd}$ miktarının arttığını belirtmişlerdir.

Artan dozlarda $\mathrm{Cd}$ uygulanmış bitki yapraklarının klorofil miktarları kontrol bitkilerine oranla azalma göstermiştir (Tablo 3). Kadmiyum dozlarındaki artış, andız otu, fener otu ve sığırkuyruğu bitkilerinin klorofil miktarı 21.2-51.8 arasında bir değişim göstermiştir. Kadmiyum

Tablo 3. Kadmiyumun farklı doz uygulamalarının, andız otu, fener otu ve sığırkuyruğu bitkilerinin yaş ağırlık, kuru ağırlık, klorofil, GSH ve bitkideki kadmiyum konsantrasyonları üzerine etkileri

\begin{tabular}{|c|c|c|c|c|c|c|}
\hline Çeşitler & $\begin{array}{c}\text { Doz } \\
\left(\mathrm{mg} \mathrm{kg}^{-1}\right)\end{array}$ & $\begin{array}{l}\text { Kuru Ağırlık } \\
\quad\left(\mathrm{g} \text { bitki }{ }^{-1}\right)\end{array}$ & $\begin{array}{l}\text { Klorofil } \\
\text { (SPAD) }\end{array}$ & $\begin{array}{c}\mathrm{GSH} \\
\left(\mu \mathrm{g} \mathrm{mL}^{-1}\right)\end{array}$ & $\begin{array}{c}\mathrm{Cd} \\
\text { konsantrasyonu } \\
\left(\mathrm{mg} \mathrm{kg}^{-1}\right)\end{array}$ & $\begin{array}{l}\text { Cd içeriği } \\
\left(\mu \mathrm{g} \text { bitki }^{-1}\right)\end{array}$ \\
\hline & 0 & $2.25 \mathrm{j}$ & $31.3 \mathrm{f}$ & $300 \mathrm{~g}$ & $0.01 \mathrm{~g}$ & $0.02 \mathrm{~g}$ \\
\hline & 5 & 2.541 & $28.3 \mathrm{~g}$ & $352 \mathrm{~d}$ & $4.35 \mathrm{f}$ & $11.1 \mathrm{f}$ \\
\hline \multirow[t]{5}{*}{ Andiz otu } & 10 & 2.651 & $27.0 \mathrm{~h}$ & $326 \mathrm{e}$ & $4.55 \mathrm{f}$ & $12.1 \mathrm{f}$ \\
\hline & 20 & $1.25 \mathrm{n}$ & $24.1 \mathrm{j}$ & 2621 & 6.47 e & $8.07 \mathrm{f}$ \\
\hline & 40 & $1.41 \mathrm{~m}$ & $21.2 \mathrm{~m}$ & $298 \mathrm{hg}$ & $8.85 \mathrm{~d}$ & $12.4 \mathrm{f}$ \\
\hline & 0 & $9.22 \mathrm{a}$ & $31.2 \mathrm{f}$ & $574 \mathrm{a}$ & $0.01 \mathrm{~g}$ & $0.09 \mathrm{~g}$ \\
\hline & 5 & $8.20 \mathrm{~b}$ & $22.5 \mathrm{k}$ & $371 \mathrm{c}$ & $4.33 \mathrm{f}$ & $35.5 \mathrm{dc}$ \\
\hline \multirow[t]{5}{*}{ Fener otu } & 10 & $7.41 \mathrm{c}$ & $24.3 \mathrm{j}$ & $377 \mathrm{c}$ & $6.33 \mathrm{e}$ & $46.9 \mathrm{~b}$ \\
\hline & 20 & $5.94 \mathrm{~d}$ & 25.61 & $315 \mathrm{f}$ & $6.57 \mathrm{e}$ & $39.0 \mathrm{c}$ \\
\hline & 40 & $3.52 \mathrm{~h}$ & $24.6 \mathrm{j}$ & $390 \mathrm{~b}$ & $10.0 \mathrm{c}$ & $35.2 \mathrm{dc}$ \\
\hline & 0 & $3.50 \mathrm{~h}$ & $51.8 \mathrm{a}$ & $224 \mathrm{j}$ & $0.01 \mathrm{~g}$ & $0.03 \mathrm{~g}$ \\
\hline & 5 & $4.96 \mathrm{e}$ & $43.8 \mathrm{c}$ & 2551 & $6.50 \mathrm{e}$ & $32.2 \mathrm{ed}$ \\
\hline \multirow[t]{3}{*}{ Siğırkuyruğu } & 10 & $3.96 \mathrm{f}$ & $41.7 \mathrm{~d}$ & $202 \mathrm{k}$ & $13.8 \mathrm{~b}$ & $54.6 \mathrm{a}$ \\
\hline & 20 & $3.65 \mathrm{~g}$ & $46.1 \mathrm{~b}$ & $289 \mathrm{~h}$ & $13.5 \mathrm{~b}$ & $49.3 \mathrm{~b}$ \\
\hline & 40 & $1.83 \mathrm{k}$ & $38.9 \mathrm{e}$ & $192 \mathrm{~m}$ & $15.6 \mathrm{a}$ & $28.5 \mathrm{e}$ \\
\hline \multicolumn{7}{|l|}{$\operatorname{Doz}\left(\mathrm{mg} \mathrm{kg}^{-1}\right)$} \\
\hline 0 & & $4.99 \mathrm{~B}$ & $38.1 \mathrm{~A}$ & $366 \mathrm{~A}$ & $0.01 \mathrm{E}^{*}$ & $0.05 \mathrm{D}^{*}$ \\
\hline 5 & & $5.23 \mathrm{~A}$ & $31.5 \mathrm{~B}$ & $326 \mathrm{~B}$ & $5.06 \mathrm{D}$ & $26.3 \mathrm{C}$ \\
\hline 10 & & $4.67 \mathrm{C}$ & $31.0 \mathrm{C}$ & $302 \mathrm{C}$ & $8.22 \mathrm{C}$ & $37.9 \mathrm{~A}$ \\
\hline 20 & & $3.61 \mathrm{D}$ & $31.9 \mathrm{~B}$ & $289 \mathrm{D}^{*}$ & $8.85 \mathrm{~B}$ & $32.1 \mathrm{~B}$ \\
\hline 40 & & $2.25 \mathrm{E}^{*}$ & $28.2 \mathrm{D}^{*}$ & $293 \mathrm{D}^{*}$ & $11.5 \mathrm{~A}$ & $25.4 \mathrm{C}$ \\
\hline \multicolumn{7}{|l|}{ Çeşit } \\
\hline And1z otu & & $2.02 \mathrm{C}^{*}$ & $26.4 \mathrm{~B}$ & $308 \mathrm{~B}$ & $4.85 \mathrm{C}^{*}$ & $8.73 \mathrm{~B}^{*}$ \\
\hline Fener otu & & $6.86 \mathrm{~A}$ & $25.6 \mathrm{C}^{*}$ & $405 \mathrm{~A}$ & $5.45 \mathrm{~B}$ & $31.3 \mathrm{~A}$ \\
\hline Siğırkuyruğu & & $3.58 \mathrm{~B}$ & $44.4 \mathrm{~A}$ & $232 \mathrm{C}^{*}$ & $9.88 \mathrm{~A}$ & $32.9 \mathrm{~A}$ \\
\hline
\end{tabular}


metalinin yoğunluğuna bağlı olarak bitki büyümesindeki gerilemenin, fotosentez ve klorofil içeriğinin azalmasının, karbon fiksasyonunun engellenmesi sonucu olduğu belirtilmiştir (Hassan ve ark., 2005). Yüksek yoğunluktaki Cd dozlarının klorofil biyosentezini bozmasının en önemli nedeni, klorofil biyosentezinde görev yapan protoklorofil reduktaz ile aminolevulinik asit sentezini engellemesidir. Ayrıca, ağır metallerin serbest radikal oluşumuna yol açtığı ve bu yolla tilakoid membran lipitlerinin oksidatif yıkımına neden olduğu, buna bağlı olarak klorofil yıkımının $\operatorname{arttığ1~ve~sentezinin~engellendiği~bilinmektedir~}$ (Zengin ve Munzuroğlu, 2005).

Tablo 3'te görüleceği gibi; artan $\mathrm{Cd}$ uygulamalarında, bitkilerin GSH konsantrasyonlarında azalmaya neden olmuştur. En düşük GSH konsantrasyonu $232 \mu \mathrm{g} \mathrm{mL} \mathrm{m}^{-1}$ ile sığırkuyruğunda, en yüksek değer ise $405 \mu \mathrm{g} \mathrm{mL}-1$ ile fener otundan elde edilmiştir. Dozlar arasındaki GSH konsantrasyonu en düşük $\left(289 \mu \mathrm{g} \mathrm{mL}^{-1}\right) 20$

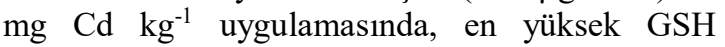
konsantrasyonu $\left(366 \mu \mathrm{g} \mathrm{mL}^{-1}\right)$ ise kontrol uygulamasında tespit edilmiştir. Kadmiyum, çevre korumacıları tarafından tehlikeli bir ağır metal olarak bildirilmiştir. Kadmiyum, enzim ve proteinlerdeki thiol (-SH) gruplarına büyük affinite gösterdiğinden enzim aktivitesini önemli ölçüde engellemek suretiyle bitkilere kuvvetli toksik olabilmektedir (Bergmann, 1993). Benzer sonuçlar Dağhan ve ark. (2012) tarafindan da bildirilmiştir. Araştırmacılar, tütün bitkisi ile yapmış oldukları çalışmalarında, artan $\mathrm{Cd}$ dozlarının - $\mathrm{SH}$ (indirgenmiş glutatyon) konsantrasyonlarında azalmaya neden olduğunu belirtmiştirler. Ayrıca Cd'un bitki bünyesinde; proteinlerin - $\mathrm{SH}$ gruplarındaki enzimleri inaktive ettiklerini, fotosentezi engellediklerini, stomaların kapanmasina, transprasyon ile su kaybının azalmasına ve klorofil biyosentezinin bozulmasina neden olduğunu belirtmişlerdir.

Bitkiler, yeşil aksamlarında biriktirdikleri $\mathrm{Cd}$ konsantrasyonları ve içerikleri bakımından incelendiğinde; yeșil aksamında en fazla $\mathrm{Cd}$ biriktiren bitki sırasıyla sığırkuyruğu bitkisi (9.88 $\mathrm{mg} \mathrm{kg}^{-1}$ ve $32.9 \mu \mathrm{g}$ bitki ${ }^{-1}$ ), fener otu (5.45 mg kg-1 ve $\left.31.3 \mu \mathrm{g} \mathrm{bitki}^{-1}\right)$ ve andız otu (4.85 $\mathrm{mg} \mathrm{kg}^{-1}$ ve $8.73 \mu \mathrm{g} \mathrm{bitki}{ }^{-1}$ ) bitkileri olmuştur (Tablo 3 ). Bitkilerin $\mathrm{Cd}$ içeriği, Cd dozlarının artışı ile birlikte tüm bitkilerde (andız otu, fener otu ve sığırkuyruğu) kontrol bitkisine göre artış göstermiştir. Sığırkuyruğu bitkisi fener otu bitkisinden daha az kuru ağırlık üretmesine rağmen en fazla Cd'u dokularında biriktirmiştir. Dozlar arasında tüm $\mathrm{Cd}$ uygulamalarında elde edilen sonuçlar Alloway (1995)'den uyarlanan, bitkilerde Cd sınır değerlerinin kritik konsantrasyon (5-30 mg Cd $\mathrm{kg}^{-1}$ ) aralığında olduğu belirlenmiştir. Fediuc ve Erdei (2002), tarafından farklı iki kamış türünde yapılan araştırmada $\mathrm{Cd}$ dozlarına göre, kök ve gövdede $\mathrm{Cd}$ konsantrasyonunun arttığını belirtmiştirler.

\subsection{Bakır denemesi}

Artan $\mathrm{Cu}$ uygulamalarında bitkiler arasında en düşük bitki kuru ağırlığ1 $2.11 \mathrm{~g}$ bitki $^{-1}$ ile andız otunda, en yüksek değer ise $4.61 \mathrm{~g} \mathrm{bitki}^{-1}$ ile fener otunda; dozlar arasındaki en düşük bitki kuru ağırlığı $\quad\left(2.28 \quad \mathrm{~g} \quad\right.$ bitki $\left.^{-1}\right) \quad 800 \quad \mathrm{mg} \quad \mathrm{Cu} \quad \mathrm{kg}^{-1}$ uygulamasında, en yüksek bitki kuru ağırlığ 1 (4.97 $\mathrm{g}$ bitki $^{-1}$ ) ise kontrol uygulamasinda tespit edilmiștir (Tablo 4). MacFarlane ve Burchett (2002), Avicennia marina fidelerinde yapmış oldukları çalışmada $100 \mu \mathrm{g} \mathrm{Cu} \mathrm{g}{ }^{-1}$ uygulamasından $400 \mu \mathrm{g} \mathrm{Cu} \mathrm{g^{-1 }}$ uygulamasına gidildikçe toplam biokütlede azalma ve kök gelişiminde gerileme olduğunu gözlemlemişlerdir. Ayrıca fide dokularında yüksek oranda $\mathrm{Cu}$ birikimine rastlanırken, yaprak alanı ve yaprak sayısının da azaldığını bildirmişlerdir.

Bakır dozlarının artışı ile birlikte klorofil düzeyleri tüm bitkilerde düşüş göstermiştir (Tablo 4). Bakır elementi içeren topraklarda yetiştirilen Empetrum nigrum'un klorofil miktarının kontrol bitkilerine göre azalma gösterdiği Wagner (1999), tarafindan belirtilmiştir.

Artan $\mathrm{Cu}$ uygulamalarında, bitkiler arasinda en düşük GSH konsantrasyonu $205 \mu \mathrm{g} \mathrm{mL}^{-1}$ ile andız otunda, en yüksek ise $477 \mu \mathrm{g} \mathrm{mL}^{-1}$ ile fener otunda saptanmıştır.

Bakır uygulamalarıyla birlikte bitkilerin yeșil aksamlarındaki $\mathrm{Cu}$ konsantrasyonunda bir azalma görülmüştür (Tablo 4). Bitkilerin $\mathrm{Cu}$ içeriği ise kontrol bitkisine göre azalma göstermiștir. Fener otu bitkisi en fazla $\mathrm{Cu}$ konsantrasyonuna $(60.1 \mathrm{mg}$ $\left.\mathrm{kg}^{-1}\right)$ ve içeriğine $\left(243 \mu \mathrm{g}\right.$ bitki $\left.{ }^{-1}\right)$ sahipken, bunu sığırkuyruğu (46.8 mg kg-1, $194 \mu \mathrm{g}$ bitki $^{-1}$ ) ve andiz otu (18.0 mg kg-1, $39.5 \mu \mathrm{g}$ bitki $\left.^{-1}\right)$ bitkileri takip etmiştir. Tüm $\mathrm{Cu}$ uygulamalarında elde edilen sonuçlar, bitkilerin $\mathrm{Cu}$ konsantrasyonunun kritik konsantrasyon (20-100 mg Cu $\left.\mathrm{kg}^{-1}\right)$ aralığında olduğunu göstermiştir (Alloway, 1995). Balcan (2014); bakırın 100 ve $500 \mathrm{mg} \mathrm{kg} \mathrm{kg}^{-1}$ konsantrasyonlarında sürgün gelişiminde gerileme ve yapraklarda kloroz gözlemlendiği ve Rosmarinus officinalis L. bitkisinde yapraklarının $\mathrm{Cu}$ içeriği, uygulanan $\mathrm{Cu}$ konsantrasyonu ile birlikte arttığını belirtmiştir.

\section{Sonuç ve Öneriler}

Her geçen gün ağır metallerin topraklardaki konsantrasyonları birçok faaliyet (endüstri, tarım, 
Tablo 4. Bakırın farklı doz uygulamalarının, andız otu, fener otu ve sığırkuyruğu bitkilerinin yaş ağırlık, kuru ağırlık, klorofil, GSH ve bitkideki bakır konsantrasyonları üzerine etkileri

\begin{tabular}{|c|c|c|c|c|c|c|}
\hline Çeşitler & $\begin{array}{c}\text { Doz } \\
\left(\mathrm{mg} \mathrm{kg}^{-1}\right)\end{array}$ & $\begin{array}{c}\text { Kuru Ağırlık } \\
\left(\mathrm{g} \mathrm{bitki}{ }^{-1}\right)\end{array}$ & $\begin{array}{l}\text { Klorofil } \\
\text { (SPAD) }\end{array}$ & $\begin{array}{c}\mathrm{GSH} \\
\left(\mu \mathrm{g} \mathrm{mL}^{-1}\right)\end{array}$ & $\begin{array}{c}\mathrm{Cu} \\
\text { konsantrasyonu } \\
\left(\mathrm{mg} \mathrm{kg}^{-1}\right)\end{array}$ & $\begin{array}{l}\text { Cu içeriğgi } \\
\left(\mu \mathrm{g} \mathrm{bitki}{ }^{-1}\right)\end{array}$ \\
\hline \multirow{5}{*}{ Andiz otu } & 0 & $2.75 \mathrm{f}$ & $33.4 \mathrm{~d}$ & $216 \mathrm{~m}$ & $11.5 \mathrm{~g}$ & $31.5 \mathrm{~h}$ \\
\hline & 100 & $2.33 \mathrm{~g}$ & $31.8 \mathrm{fe}$ & $312 \mathrm{~h}$ & $15.5 \mathrm{~g}$ & $36.1 \mathrm{~h}$ \\
\hline & 200 & $1.44 \mathrm{~h}$ & $0.00 \mathrm{k}$ & $0.00 \mathrm{n}$ & $1.27 \mathrm{~h}$ & 1.821 \\
\hline & 400 & $1.70 \mathrm{~h}$ & $33.2 \mathrm{ed}$ & $221 \mathrm{~m}$ & $23.0 \mathrm{f}$ & $39.1 \mathrm{~h}$ \\
\hline & 800 & $2.31 \mathrm{~g}$ & $31.1 \mathrm{f}$ & $276 \mathrm{j}$ & $38.5 \mathrm{e}$ & $88.9 \mathrm{~g}$ \\
\hline \multirow{5}{*}{ Fener otu } & 0 & $6.03 \mathrm{a}$ & $27.3 \mathrm{~g}$ & $491 \mathrm{~b}$ & $25.5 \mathrm{f}$ & $154 \mathrm{e}$ \\
\hline & 100 & $5.75 \mathrm{~b}$ & $24.4 \mathrm{~h}$ & $357 \mathrm{f}$ & $47.7 \mathrm{~d}$ & $274 b$ \\
\hline & 200 & $5.70 \mathrm{~b}$ & $24.3 \mathrm{~h}$ & $450 \mathrm{c}$ & $53.3 \mathrm{c}$ & $304 \mathrm{a}$ \\
\hline & 400 & $3.23 \mathrm{e}$ & 21.61 & $698 \mathrm{a}$ & $85.9 \mathrm{a}$ & $277 \mathrm{~b}$ \\
\hline & 800 & $2.34 \mathrm{~g}$ & $18.2 \mathrm{j}$ & $391 \mathrm{~d}$ & $87.9 \mathrm{a}$ & $206 \mathrm{~d}$ \\
\hline \multirow{5}{*}{ Sığgrkuyruğu } & 0 & $6.12 \mathrm{a}$ & $39.4 \mathrm{a}$ & $336 \mathrm{~g}$ & $26.2 \mathrm{f}$ & $161 \mathrm{e}$ \\
\hline & 100 & $4.10 \mathrm{~d}$ & $37.9 \mathrm{~b}$ & $332 \mathrm{~g}$ & $47.3 \mathrm{~d}$ & $194 \mathrm{~d}$ \\
\hline & 200 & $4.73 \mathrm{c}$ & $36.0 \mathrm{c}$ & $372 \mathrm{e}$ & $49.8 \mathrm{dc}$ & $236 \mathrm{c}$ \\
\hline & 400 & $4.83 \mathrm{c}$ & $36.7 \mathrm{cb}$ & 2851 & $52.5 \mathrm{c}$ & $253 \mathrm{c}$ \\
\hline & 800 & $2.17 \mathrm{~g}$ & $31.3 \mathrm{f}$ & $265 \mathrm{k}$ & $58.1 \mathrm{~b}$ & $126 \mathrm{f}$ \\
\hline \multicolumn{7}{|l|}{$\overline{\operatorname{Doz}\left(\mathrm{mg} \mathrm{kg}^{-1}\right)}$} \\
\hline 0 & & $4.97 \mathrm{~A}$ & $33.4 \mathrm{~A}$ & $348 \mathrm{~B}$ & $21.1 \mathrm{D}^{*}$ & $115 \mathrm{D}^{*}$ \\
\hline 100 & & $4.06 \mathrm{~B}$ & $31.4 \mathrm{BA}$ & $334 \mathrm{C}$ & $36.8 \mathrm{C}$ & $168 \mathrm{~B}$ \\
\hline 200 & & $3.96 \mathrm{~B}$ & $20.1 \mathrm{D}^{*}$ & $274 \mathrm{E}^{*}$ & $34.8 \mathrm{C}$ & $181 \mathrm{~A}$ \\
\hline 400 & & $3.25 \mathrm{C}$ & $30.5 \mathrm{~B}$ & $401 \mathrm{~A}$ & $53.8 \mathrm{~B}$ & $190 \mathrm{~A}$ \\
\hline 800 & & $2.28 \mathrm{D}^{*}$ & $26.9 \mathrm{C}$ & $311 \mathrm{D}$ & $61.5 \mathrm{~A}$ & $140 \mathrm{C}$ \\
\hline \multicolumn{7}{|l|}{ Çeşit } \\
\hline And1z otu & & $2.11 \mathrm{C}^{*}$ & $25.9 \mathrm{~B}$ & $205 \mathrm{C}^{*}$ & $18.0 \mathrm{C}^{*}$ & $39.5 \mathrm{C}^{*}$ \\
\hline Fener otu & & $4.61 \mathrm{~A}$ & $23.1 \mathrm{C}^{*}$ & $477 \mathrm{~A}$ & $60.1 \mathrm{~A}$ & $243 \mathrm{~A}$ \\
\hline Siğırkuyruğu & & $4.39 \mathrm{~B}$ & $36.3 \mathrm{~A}$ & $318 \mathrm{~B}$ & $46.8 \mathrm{~B}$ & $194 \mathrm{~B}$ \\
\hline
\end{tabular}

*: Aynı satır ve sütun içinde aynı harfle gösterilen ortalamalar arasındaki fark Duncan-testine göre $\mathrm{P} \leq 0.01$ hata sınırları içinde önemsizdir. Büyük harfler ağır metal dozu ve bitki ortalamalarına ait esas etkilerin, küçük harfler ise bitki x doz interaksiyonlarına ait ortalamaların karşılaştırılmasıdır.

madencilik, vb.) sonucunda artmaktadır. Özellikle tarım topraklarının ağır metallerden temizlenmesi insan sağlığ 1 ve tarımsal üretim açısından önem arz etmektedir. $\mathrm{Bu}$ nedenle ağır metallerle kirlenmiş toprakların temizlenmesinde, fiziksel ve kimyasal yöntemlere göre ekonomik, ucuz, çevre dostu, uygulaması kolay olan fitoremediasyon yöntemi günümüzde en çok tercih edilen yöntemdir. $\mathrm{Bu}$ yöntemde, hızlı büyüyebilen ve bol yeșil aksam üretebilen, topraktaki metalleri hasat edilebilen kısımlarına nakledebilen hiperakümülatör bitkiler kullanılmaktadır. Bu çalışmada amaç çabuk büyüyen ve bol yeşil aksam üretebilen andız otu, fener otu ve sığırkuyruğu bitkilerinin ağır metallerle kirlenmiş toprakların temizlenmesinde kullanım potansiyelleri araștırılmıştır. Bu konuda belirtilen bitkilerle yapılmış çalışmalar yok denecek kadar azdır.

Araştırma sonuçlarına göre bitkilerin artan dozlarda ağır metale bağlı olarak gösterdikleri en belirgin tepki ürettikleri biyokütle miktarlarının azalması şeklinde ortaya çıkmıştır. Detaylı yapılan incelemelerde ağır metale bağlı olarak bitki yeşil aksamında ağır metalin toksik seviyeye ulaşmasına veya diğer besin elementlerini engellenme etkilerine bağlı olarak SPAD metre ölçümleriyle belirlenen klorofil düzeylerinin yapraklarda değişmesi şeklinde ortaya çıkmıştır.

Diğer yandan, Her bitkinin ağır metal alım ve biriktirme yeteneğinin uygulanan metale ve uygulama dozuna göre farklılık gösterdiği tespit edilmiştir. Fener otu bitkisinin tüm ağır metal uygulamalarında en fazla kuru ağırlık üreten ve bünyesinde en fazla ağır metal biriktirebilen bitki olduğu saptanmıştır. Sığırkuyruğu bitkisi ise fener otu bitkisine yakın miktarlarda kuru ağırlık üretmiş ve ağır metal biriktirmiştir. Her iki bitkinin $\mathrm{Ni}, \mathrm{Cd}$ ve $\mathrm{Cu}$ ile kirlenmiş toprakların temizlenmesinde kullanım potansiyeline sahip bitkiler oldukları tespit edilmiştir.

Gelecekte çalışmanın toprağa ilave edilebilecek ve metal alımını artıracak maddelerin ve bitkilerin yalnızca bir metali değil birden fazla metali akümüle edebilme yeteneklerinin araştırılması gerekmektedir. Ayrıca, ağır metal toksisitelerine karşı bitkilerinin biyokimyasal ve fizyolojik tepkilerini araştırmada fitoremediasyon etkinliğinin arttırılmasında önemli bir adım olacaktır. 


\section{Teşekkür}

Doktora çalışmalarımın gerçekleştirilmesinde; iki yıl boyunca gösterdiği destek, değerli bilgilerini ve yardımları için Prof. Dr. Mehmet ARSLAN'a, deneylerdeki yardımları ve değerli fikirleri, güven ve teşvikleri için Prof. Dr. Nurcan KÖLELI ve Doç. Dr. Hatice DAĞHAN'a teşekkür ederim.

\section{Kaynaklar}

Alam, M.M., Hayat, S., Ali, B., Ahmad, A., 2007. Effect of 28-homobrassinolide treatment on nickel toxicity in Brassica Juncea. Photosynthetica, 45(1): 139142.

Alloway, B.J., 1995. Heavy metals in soils. Blackie Academic and Professioal. Chapman and Hall press, London, UK. http://books.google.co.in/books/about/ Heavy_Metals_in_Soils. html?id=CX1GwLBhkC4C (Erişim tarihi: 08.10.2014).

Alpaslan, M., Güneș, A., İnal, A., 1998. Deneme Tekniği. Ankara Üniversitesi Ziraat Fakültesi Yayınlar1 No: 1502, Ders Kitab1, Ankara.

Anonymous, 1951. Soil Survey Staff, Soil Survey Manual. U.S. Department of Agriculture, Handbook No: 18. U.S Goverment Print Office, Washington.

Balcan, M., 2014. Biberiyede (Rosmarinus officinalis L.) bakır uygulamalarının bazı fizyolojik etkileri. Yüksek lisans tezi, Gaziantep Üniversitesi Fen Bilimleri Enstitüsü, Gaziantep.

Bayçu, G., Önal, M., 1993. An investigation of the levels of cadmium and lead in the soils and in the leaves of selected specimens of ailanthus altissima found growing beside a freeway in İstanbul. İstanbul Üniversitesi Fen Fakültesi Biyoloji Dergisi, 56: 2134.

Bek, Y., 1986. Araştırma ve Deneme Metotları. Çukurova Üniversitesi Ziraat Fakültesi, Ders Notu, Yayın No: 92, Adana.

Bergmann, W., 1993. Emährungsstörungen bei Kulturpflanzen. Dritte, Erweiterte Auflage, Gustav Fischer Verlag Jena, Stuttgart.

Bouyoucus, G.J., 1952. A recalibration of hydrometer for making mechanical analysis of soils. Agronomy Journal, 43: 434-438.

Bremner, J.M., 1965. Total Nitrogen. In: Methods of Soil Analysis. Part 2: Chemical and Microbiological Properties. Edited by C.A. Black et al., Agronomy Series 9., American Society of Agronomy, Madison, Wisconsin, pp. 1149-1178.

Çakmak, İ., Marschner, H., 1992. Magnesium deficiency and high light intensity enhance activities of superoxide dismutase, ascorbate peroxidase, and glutathione reductase in bean leaves. Plant Physiology, 98(4): 1222-1227.

Çepel, N., 2003. Ekolojik Sorunlar ve Çözümleri. TÜBİTAK Popüler Bilim Kitapları, Ankara.

Dağhan, H., 2007. Fitoremediasyon: Bitki kullanılarak kirlenmiş alanların temizlenmesi. GAP $V$. Tarım Kongresi, Bildiri Kitabı, 17-19 Ekim, Şanlıurfa, s. 362-367.
Dağhan, H., 2011. Doğal kaynaklarda ağır metal kirliliğinin insan sağlı̆̆ 1 üzerine etkileri. Mustafa Kemal Üniversitesi Ziraat Fakültesi Dergisi, 16(2): $15-25$.

Dağhan, H., Köleli, N., Uygur, V., Arslan, M., Önder, D., Göksun, V., Ağca, N., 2012. Kadmiyum ile kirlenmiş toprakların fitoekstraksiyonla arıtımında transgenik tütün bitkisinin kullanımının araştırılması. Toprak ve Su Dergisi, 1(1): 1-6.

Dağhan, H., Öztürk, M., 2015. Soil pollution in Turkey and remediation methods. In: K.R. Hakeem, M. Sabir, M. Ozturk, A. Mermut (Eds), Soil Remediation and Plants: Prospects and Challenges, September 2015, Academic Press., Elsevier, New York, pp. 287-312.

Ewais, E.A., 1997. Effects of cadmium, nicel and lead on growth, chlorophyll content and proteins of weeds. Biologia Plantarum, 39(3): 403-410.

Fediuc, E., Erdei, L., 2002. Physiological and biochemical aspects of cadmium toxicity and protective mechanisms in Phragmites ausstralis and Typha latifolia. Journal of Plant Physiology, 159(3): 265-271.

Foyer, C.H., Noctor, G., 2005. Redox homeostis and antioxidant signaling: A metabolic interface between stress perception and physiological responses. Plant Cell, 17(7): 1866-1875.

Glass, D.J., 1999. Economic patential of phytoremediation. In: I. Raskin, B.D. Ensley (Eds), Phyforemediation of Toxic Metals: Using Plants to Clean Up the Environment, John Wiley and Sans, New York, pp. 15-31.

Güler, Ç., Çobanoğlu, Z., 1997. Kimyasallar ve Çevre. Çevre Sağlığı Temel Kaynak Dizisi, 50, Ankara.

Hassan, M.J., Wang, F., Ali, S., Zhang, G., 2005. Toxic effects of cadmium on rice as affected by nitrogen fertilizer form. Plant and Soil, 277(1): 359-365.

Kabata-Pendias, A., Mukherjee, A.B., 2007. Trace elements from soil to human. Springer Science \& Business Media Book.

Kacar, B., 1995. Bitki ve Toprağın Kimyasal Analizleri, III. Toprak Analizleri. Ankara Üniversitesi Ziraat Fakültesi, Eğitim, Araștırma ve Geliştirme Vakfı Yayınları, No: 3, Ankara.

Kalınbacak, K., Yurdakul, İ., Gedikoğlu, İ., 2012. Buğdayda kadmiyumun toksiklik sınırının belirlenmesi ve bazı ekstraksiyon yöntemlerinin karşılaştırılması. Toprak Su Dergisi, 1(1): 28-37.

Karaca, A., Turgay, O.C., 2012. Toprak kirliliği. Toprak Bilimi ve Bitki Besleme Dergisi, 1(1): 13-19.

Kılıç, Ş., Ağca, N., Karanlık, S., Şenol, S., Aydın, M., Yalçın, M., Çelik, İ., Evrendilek, F., Uygur, V., Doğan, K., Aslan, S., Çullu, M.A., 2008. Amik ovasının detaylı toprak etütleri, verimlilik çalışması ve arazi kullanım planlaması. Devlet Planlama Teşkilatı (DPT) Projesi, Proje No: DPT2002K120480, Hatay.

Kocaer, F.O., Başkaya, H.S., 2003. Metallerle kirlenmiş toprakların temizlenmesinde uygulanan teknolojiler. 
Uludă̆ Üniversitesi Mühendislik-Mimarlık Fakültesi Dergisi, 8(1): 121-131.

Köleli, N., Kantar, Ç., 2006. Fosfat kayası, fosforik asit ve fosforlu gübrelerdeki toksik ağır metal $(\mathrm{Cd}, \mathrm{Pb}$, Ni, As) konsantrasyonu. Ekoloji Dergisi, 14(55): 15.

Lindsay, W.L., 1979. Chemical Equilibria in Soils. Wiley and Sons, N.Y.

Lindsay, W.L., Norvell, W.A., 1978. Development of a DTPA soil test for zinc, iron, manganese, and copper. Soil Science Society of America Journal, 42: 421-428.

Loeppert, R.H., Suarez, D.L., 1996. Carbonate and gypsum. In: D.L. Spark (Ed), Methods of Soil Analysis Part 3-Chemical Methods, Soil Science Society of America, American Society of Agronomy, Madison, Wisconsin, USA, pp. 437-474.

MacFarlane, G.R., Burchett, M.D., 2002. Toxicity, growth and accumulation relationships of copper, lead and zinc in grey mangrove Avicennia marina (Forsk.) Vierh. Marine Environmental Research, 54(1): 65-84.

Millar, A.H., Mittova, V., Kiddle, G., Heazlewood, J.L., Bartoli, C.G., Theodoulou, F.L., Foyer, C.H., 2003. Control of ascorbate synthesis by respiration and its implications for stress responses. Plant Physiology, 133(2): 443-447.

Olsen, S.R., Cole, C.V., Watanabe, F.S., Dean, L.A., 1954. Estimation of Available Phosphorus in Soils by Extraction with Sodium Bicarbonate. US Dept. of Agric. Cric. 939.

Pandey, N., Sharma, C.P., 2002. Effect of heavy metals $\mathrm{Co}^{2+}, \mathrm{Ni}^{2+}$ and $\mathrm{Cd}^{2+}$ on growth and metabolism of cabbage. Plant Science, 163(4): 753-758.

Rausch, T., Gromes, R., Liedschulte, V., Muller, I., Bogs, J., Galovic, V., Wachter, A., 2007. Novel insight into the regulation of GSH biosynthesis in higher plants. Journal of Plant Biology, 9(5): 565572.

Richards, L.A., 1954. Diagnosis and Improvement of Saline and Alkali Soils. United States Department of Agriculture Handbook 60.

Scheffer, F., Schachtschabel, P., 1989. Lehrbuch der Bokerkunde, 12 Aufl. Ferdinand Enke Verlag, Stuttgart.

Wagner, G.J., 1999. Accumulation of cadmium in crop plants and its consequences to human health. Advances in Agronomy, 51: 173-212.

Yusuf, M., Fariduddin, Q., Hayat, S., Ahmad, A., 2011. Nickel: An overview of uptake, essentiality and toxicity in plants. Bulletin of Environmental Contamination and Toxicology, 86(1): 1-17.

Zengin, K.F., Munzuroğlu, Ö., 2005. Fasulye fidelerinin (Phaseolus vulgaris L. Strike) klorofil ve karotenoid miktarı üzerine bazı ağır metallerin $\left(\mathrm{Ni}^{+2}, \mathrm{Co}^{+2}, \mathrm{Cr}^{+3}\right.$, $\mathrm{Zn}^{+2}$ ) etkileri. Furat Üniversitesi Fen ve Mühendislik Bilimleri Dergisi, 17(1): 164-172. 